\title{
水平2方向地震動の軌跡特性が 構造物の2方向弾塑性応答に及ぼす影響
}

\author{
井上 和真 1 - 渡辺 和明 $2 \cdot$ 五十嵐 晃 3 \\ 1正会員 大成建設株式会社 原子力本部（テ163-0606 東京都新宿区西新宿1-25-1新宿センタービル） \\ E-mail: inukzm00@pub.taisei.co.jp \\ 2正会員 大成建設株式会社 原子力本部（†163-0606 東京都新宿区西新宿1-25-1新宿センタービル） \\ E-mail: kwatanab@ce.taisei.co.jp \\ 3正会員 京都大学防災研究所教授（广611-0011 京都府宇治市五ヶ庄） \\ E-mail: igarashi.akira.7m@kyoto-u.ac.jp
}

\begin{abstract}
本研究では, 3次元地震応答解析による耐震設計・耐震性能照查に用いる水平2方向の設計用地震動を合 理的に設定するために, 水平2方向地震動の軌跡特性が構造物の弾塑性応答に及ぼす影響について検討し た.まず，従来の振幅調整によるスペクトル適合法を2次元に拡張し，観測記録の実位相を用いた2方向ス ペクトル適合波の作成法を提案した，次に，構造物への入力エネルギー量を定量的に評価するために，従 来のエネルギースペクトルを2次元に拡張し, 水平2方向地震動の軌跡特性と地震応答の関係を調べた. 更 に，2軸非線形の地震応答が考慮できる構造モデルを用いた漸増動的解析（IDA）を行った。その結果， 水平2方向地震動として円形軌跡とした場合に，観測記録の実位相による軌跡などに比べて，構造物の弾 塑性応答が大きくなる傾向が確認された.
\end{abstract}

Key Words : bi-axial response spectrum, bi-axial energy spectrum, acceleration trajectory, spectrumcompatible accelerograms, elastic-plastic seismic response

\section{1. はじめに}

近年の目覚ましいコンピュータの演算処理能力の発達 により，様々な現象に対するモデリング技術も飛躍的に 向上している. 地震工学・耐震工学においては, 堀・市 村らの研究グループのように, 統合地震シミュレータを 用いて断層から都市域までをモデル化した大規模地震応

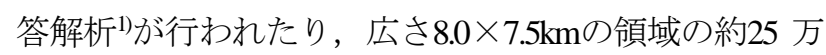
棟の建物をモデル化し, 多数の地震シナリオに対する都 市被害想定へのHPCの適用性を検討2)している例もある。 このように，一昔前では考えられない様な大規模モデル による地震応答解析を行える解析環境が整いつつある.

一方で，多次元性を考慮した実験に目を向けると，荻 本らはRC単柱橋脚を対象に水平2方向加振によるハイブ リッド載荷実験を行い，2方向加振の場合，1方向加振時 と比べて損傷が大きく, 最大耐力が低下寸る傾向を示し た ${ }^{3)}$.また, 党らは, 正方形断面鋼製橋脚に対して水平2 方向載荷のハイブリッド実験を行い，萩本らのRC単柱 における成果と同様の傾向を示した4). このように, 従 来の耐震設計で想定する1方向入力とした場合よりも,
水平 2 方向入力とした場合に, 土木構造物の地震応答特 性に違いが見られることが既往の実験で確認されている.

このように, 解析環境の向上や実験データの蓄積によ り, 水平 2 方向入力による3次元地震応答解析を用いた耐 震設計・耐震性能照査の環境が整いつつあるが，水平2 次元の地震時挙動における入力と応答の関係に着目した 研究は少なく, 水平 2 方向入力による耐震設計・耐震性 能照査体系の構築にあたっては，この入力と応答の関係 を整理することは重要な課題である.

著者らはこれまでに耐震設計・耐震性能照査におけ る水平 2 方向入力の設定法に着目した研究を行ってい るらの》。従来の水平 1 方向入力における設計用地震動の 考え方を踏襲し，設計用の応答スペクトル適合波による 水平 2 方向地震動の設定を基本方針としている. 応答ス ペクトルによって設計用地震動を定義することは, 震源 断層モデルによって作成されるサイト波とは異なり, 簡 易な1質点系の構造モデルの応答特性を加味して地震動 が定義されることを意味する。一般に，スペクトル適合 波の設定においては, 対象構造物の応答特性は考慮され ない. そのため, 曲線橋や不整形地盤中の地中構造物な 
ど，非対称な構造物の設計・照査では設定された地震動 の入力角度を変化させ，その影響を反映させる必要があ る.これまで提案した水平 2 方向入力は, 実際の地震動 が持つ複雑な軌跡では無く，1方向のスペクトル適合波 を基淮に，直交成分の位相を調整しているため，円形や 楕円形の加速度軌跡としていた．このような加速度軌跡 となる2方向入力は，目標とする2方向応答スペクトルに 適合しているため，一定の入力強度を有しているが，実 際の地震動が有寸る複雑な加速度軌跡による入力と地震 応答への影響をより定量的に分析する必要がある.

本研究では，まず，2方向応答スペクトルに適合した 複雑な加速度軌跡を有する地震動を作成するため, 従来 の1次元の振幅調整によるスペクトル適合法を2次元に拡 張し，目標とする2方向応答スペクトルへの適合法を提 案した. 提案手法は, 水平直交2成分の振幅調整を行い, 目標とする応答スペクトルに適合させるため，観測記録 などの原波の位相特性を保持することが出来る.

続いて，地震動の構造物への入力エネルギーを評価で きるエネルギースペクトル9にについて，従来の1次元から 2次元に拡張した2方向エネルギースペクトルを提案した。 これを用いて，同一の 2 方向応答スペクトルに適合した2 方向入力についても, 加速度軌跡の違いによる2方向工 ネルギースペクトルの変化を分析した.

更に，構造物の2軸非線形を考慮できるMSSモデルや ファイバーモデルを用いた水平 2 方向入力による漸増動 的解析を行い，様々な振幅レベルにおける入力地震動の 加速度軌跡が構造モデルの弾塑性応答に及ぼす影響につ いて調べた．ここで，MSSモデルは並進の自由度のみ有 する1質点系2自由度モデルであること, 塑性変形が進ん でも荷重-変位関係が負勾配にならない簡易なモデルで ある.ファイバーモデルは，MSSモデルに比べ，並進と 回転を考慮した多自由度モデルで，RCのコンクリート および鉄筋の非線形挙動を考慮できるより精緻なモデル である．なお，ファイバーモデルによる検討は，荻本 ら3)や党ら4)の水平2方向加振実験のように，単柱式橋脚 を対象としている.

\section{2方向応答スペクトルに適合した2方向入力}

\section{(1) 2方向応答スペクトル}

時間を $t$ ，水平面を $x-y$ 座標系で定義した場合に，与 えられた 2 方向入力に対する固有周期 $T$ を変数にした等方 な2次元線形弾性 1 質点振動子（図-1）の水平2次元応答 值の $x$ 方向成分, $y$ 方向成分の応答值を $d_{x}(T, t), d_{y}(T, t)$ とする. 水平 2 次元応答の動径方向の最大值 $S_{R d}(T)$ と, 固有周期 $T$ の関係を2方向応答スペクトルと呼び, この定義を式(1) に示す. また，2方向応答スペクトルの例として，減衰

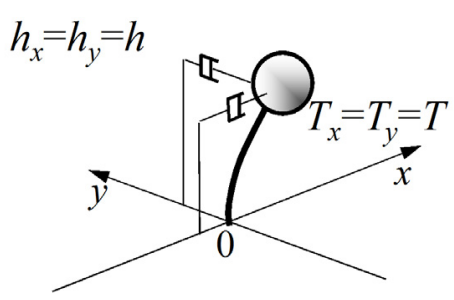

図-1２次元線形弾性 1 質点振動子

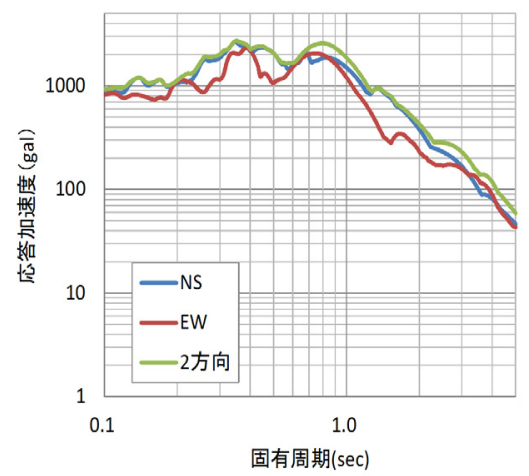

図-2２万向応答スペクトルの例（JMA神戸の観測記録）

比hは0.05とした場合の1995年兵庫県南部地震における神 戸海洋気象台の観測記録の 2 方向加速度応答スペクトル とNS成分, EW成分の加速度応答スペクトルを図-2に示 す.

$$
S_{R d}(T)=\max _{t} \sqrt{d_{x}(T, t)^{2}+d_{y}(T, t)^{2}}
$$

\section{(2) 既往の2方向応答スペクトルに適合した2方向入力}

既往の 2 方向応答スペクトルに適合した 2 方向入力の 作成法として，設計・照查用の応答スペクトルに適合し た標準波とその標準波のヒルベルト変換により求まる相 補直交成分波の組合せを用いる手法が提案されている また，相補直交成分波に楕円偏極指標を導入し，相補直 交成分波の振幅を調整した水平 2 方向入力の作成法も検 討されているの。これらの 2 方向入力地震動の作成法は, 水平直交 2 成分のうちの 1 成分を標準波とし，その直交 方向は標準波にヒルベルト変換を適用した加速度波形で あり，水平直交 2 成分間の加速度波形の位相差は全ての 周波数で $90^{\circ}$ となる. そのため，それらの 2 方向入力 の加速度軌跡は円形あるいは楕円形なものになる．この 場合, 標淮波の 1 方向入力の応答スペクトルと 2 方向入 力の 2 方向応答スペクトルは, ほぼ同一となる. 特に, 1 方向入力を基準・指針等で定義された設計・照査用ス ペクトル適合波とした場合，そのヒルベルト変換波との 2 方向応答スペクトルは， 1 方向の設計・照査用の応答 スペクトルと一致する. そのため 2 方向応答スペクトル の入力強度は従来の設計・照査用の応答スペクトルと等 価になる。 


\section{（3）複雑な加速度軌跡の2方向応答スペクトル適合波の 作成法}

実際の地震動のような複雑な加速度軌跡を持つ 2 方向 応答スペクトル適合波の作成は，互いに直交する $2 つ の ~$ 単振動が描く平面図形（リサージュ図形）の考え方に基 づいており, 直交する 2 つ単振動が同じ振動数で，か つ位相差を有していれば，2 つの単振動が描く軌跡が楕 円形になることに着目したスペクトル適合法 カである. 提案するスペクトル適合法には，棈円の長軸長を 2 方向 応答スペクトルの大きさとみなし， 2 方向応答スペクト ルの適合度に応じて楕円の長軸長を修正し，適合条件を 満足寸るまで繰り返し計算するものであり, 従来の 1 次 元の振幅調整によるスペクトル適合法 9)を 2 次元に拡張 したものと言える.

著者らは過去にリサージュ図形の概念に基づいて，2 方向入力がそれぞれの成分の目標となる 1 方向応答スペ クトルに適合し，かつ，目標の水平 2 方向応答スペクト ルに適合する方法 わを示しているが，今回の手法では, 目標となる応答スペクトルは 2 方向応答スペクトルのみ であり，それぞれの 1 万向の応答スペクトルの大きさに は制約を設けていない．また，目標となる 2 方向応答ス ペクトルへの適合の際に, 水平直交 2 方向地震動の位相 を調整する方法も考えられるが，本手法では原波の持つ 複雑な軌跡特性を保持するために，振幅のみを調整し， 観測波の実位相をそのまま適用するものとする.

地震動の観測記録など, 工学的に関連のある水平直交 2成分の加速度時刻歴を $x(t), y(t)$ とし，これらを三角関数 を用いて表記すると，

$$
\begin{aligned}
& x(t)=\frac{a_{0}}{2}+\sum_{k=1}^{N / 2-1} \sqrt{a_{k}^{2}+b_{k}^{2}} \cos \left(2 \pi f_{k} t+\phi_{x_{-} k}\right)+\frac{a_{N / 2}}{2} \cos 2 \pi f_{N / 2} t \\
& y(t)=\frac{c_{0}}{2}+\sum_{k=1}^{N / 2-1} \sqrt{c_{k}^{2}+d_{k}^{2}} \cos \left(2 \pi f_{k} t+\phi_{y_{-}}\right)+\frac{c_{N / 2}}{2} \cos 2 \pi f_{N / 2} t
\end{aligned}
$$

$k=1 \sim N / 2-1$ までのある振動数 $f_{k}$ に着目すると,

$$
\begin{aligned}
& x_{k}(t)=\sqrt{a_{k}^{2}+b_{k}^{2}} \cos \left(2 \pi f_{k} t+\phi_{x_{-} k}\right)=A_{k} \cos \left(2 \pi f_{k} t+\phi_{x_{-} k}\right) \\
& y_{k}(t)=\sqrt{c_{k}^{2}+d_{k}^{2}} \cos \left(2 \pi f_{k} t+\phi_{y_{-} k}\right)=B_{k} \cos \left(2 \pi f_{k} t+\phi_{y_{-} k}\right)
\end{aligned}
$$

となり， $x_{k}(t), y_{k}(t)$ を同時入力寸ると，水平面内で楕円軌 跡を描く. 振動数 $f_{k}$ における, 楕円軌跡の軸方向 $\theta_{k}$ は

$$
\tan 2 \theta_{k}=\frac{2 A_{k} B_{k}}{A_{k}^{2}-B_{k}^{2}} \cos \left(\phi_{y_{-} k}-\phi_{x_{-} k}\right)
$$

より，位相差を $\delta_{k}=\varphi_{x k}-\varphi_{y k k}$ とおいて，

$$
\theta_{k}=\frac{1}{2} \tan ^{-1}\left(\frac{2 A_{k} B_{k}}{A_{k}^{2}-B_{k}^{2}} \cos \delta_{k}\right)
$$

となる．直交する 2 つの棈円軸の長さを $l_{1 k} ， l_{2 k}$ とする と,

$$
l_{1 k}=\sqrt{A_{k}^{2} \cos ^{2} \theta_{k}+B_{k}^{2} \sin ^{2} \theta_{k}+2 A_{k} B_{k} \cos \theta_{k} \sin \theta_{k} \cos \delta_{k}}
$$

$$
l_{2 k}=\sqrt{A_{k}^{2} \sin ^{2} \theta_{k}+B_{k}^{2} \cos ^{2} \theta_{k}-2 A_{k} B_{k} \cos \theta_{k} \sin \theta_{k} \cos \delta_{k}}
$$

楕円軸 $l_{1 k}, \quad l_{2 k}$ の 2 つのうち, 長い方が棈円の長軸の長

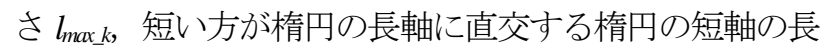

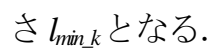

$$
\begin{aligned}
& l_{\text {max_k }}=\max \left(l_{1 k}, \quad l_{2 k}\right) \\
& l_{\text {min_k }}=\min \left(l_{1 k}, l_{2 k}\right)
\end{aligned}
$$

図-3 に振幅 $A_{k}, B_{k}$ と楕円の長軸長 $l_{\max k}$ の関係を示寸. 図-3に示すように， $x_{k}(t)$ と $y_{k}(t)$ の間で位相差を有してい ることから, 振幅 $A_{k}, B_{k}$ と楕円の長軸長 $l_{\max \_k}$ の間で, 三平方の定理の関係は成立しない，従来の 1 方向の応答 スペクトルへの適合手法における振幅修正と同様に，楕 円の長軸を 2 方向応答スペクトルのスペクトル適合度で 除すことで，修正した振幅を算出する. 水平直交 2 成分 の加速度時刻歴を $x(t), y(t)$ から算出される 2 方向加速度 応答スペクトルを $S_{R d}(T)$, 目標となる 2 方向加速度応答 スペクトルを $D S_{R}(T)$ とすると, 2 方向応答スペクトルの 適合度 $\gamma_{R}(T)$ は,

$$
\gamma_{R}(T)=\frac{S_{R d}(T)}{D S_{R}(T)}
$$

となる.このスペクトル適合度を周波数領域 $\gamma_{R K}$ で表し， 現状の楕円の長軸長 $l_{\max k}$ を 2 方向応答スペクトルの適合 度 $\gamma_{R K}$ で除すことで, 修正された楕円の長軸長 $l_{\text {max new } k \text { を }}$ 算出することが出来る.

$$
l_{\text {max } \_ \text {new } \__{-}}=\frac{l_{\text {max } \_k}}{\gamma_{R k}}
$$

式(13)の関係を，楕円の長軸の式(8)あるいは式(9)に代入 すると，

$$
\begin{aligned}
& l_{\text {max } \_ \text {new_k }}= \\
& \frac{\sqrt{A_{k}^{2} \cos ^{2} \theta_{k}+B_{k}^{2} \sin ^{2} \theta_{k}+2 A_{k} B_{k} \cos \theta_{k} \sin \theta_{k} \cos \delta_{k}}}{\gamma_{R k}} \\
& o r \\
& \frac{\sqrt{l_{\text {max } n \text { new_k }}=}}{\operatorname{lin}_{k}^{2} \sin ^{2} \theta_{k}+B_{k}^{2} \cos ^{2} \theta_{k}-2 A_{k} B_{k} \cos \theta_{k} \sin \theta_{k} \cos \delta_{k}} \\
& \gamma_{R k}
\end{aligned}
$$

式(14)，式(15)を変換すると

$$
\begin{aligned}
& l_{\text {max } \_ \text {new } \_} \\
& =\sqrt{\frac{A_{k}^{2}}{\gamma_{R k}^{2}} \cos ^{2} \theta_{k}+\frac{B_{k}^{2}}{\gamma_{R k}^{2}} \sin ^{2} \theta_{k}+2 \frac{A_{k}}{\gamma_{R k}} \frac{B_{k}}{\gamma_{R k}} \cos \theta_{k} \sin \theta_{k} \cos \delta_{k}}
\end{aligned}
$$$$
\text { or }
$$

$l_{\text {max_nnew_k }}$

$=\sqrt{\frac{A_{k}^{2}}{\gamma_{R k}^{2}} \sin ^{2} \theta_{k}+\frac{B_{k}^{2}}{\gamma_{R k}^{2}} \cos ^{2} \theta_{k}-2 \frac{A_{k}}{\gamma_{R k}} \frac{B_{k}}{\gamma_{R k}} \cos \theta_{k} \sin \theta_{k} \cos \delta_{k}}$ 式(8), 式(9) と式(16), 式(17)を比較すると, 楕円の長軸 長の修正は振幅 $A_{k}, B_{k}$ をスペクトル適合度 $\gamma_{R K}$ で除すの みで済み，実際の計算の流れでは，楕円軌跡の軸方向 $\theta_{k}$ や楕円の長軸 $l_{\max k}$ の計算は不要であることが示された. よって，修正した振幅をそれぞれ $A_{\text {new } k \text {, }}, B_{\text {new } \_ \text {とすると }}$ 式(18), (19)のように表すことができる. 


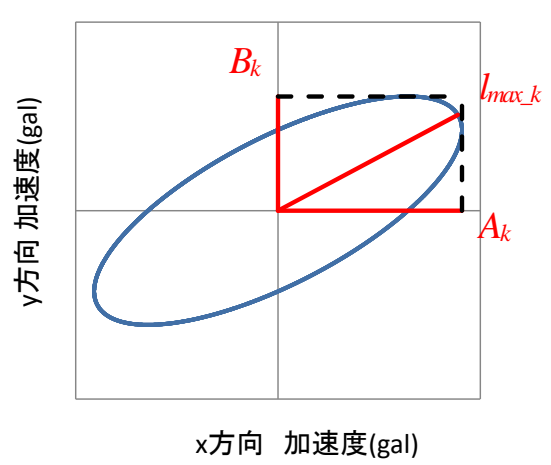

図-3＼cjkstart各振動数成分における振幅と棈円長軸のイメージ図

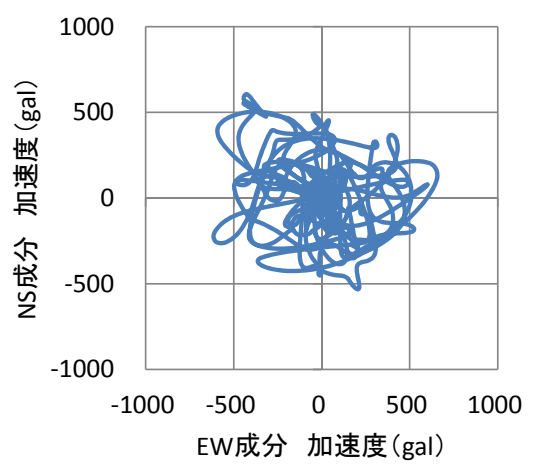

図-4＼cjkstart兵庫県南部地震 $\mathrm{JR}$ 鷹取駅観測波の加速度軌跡

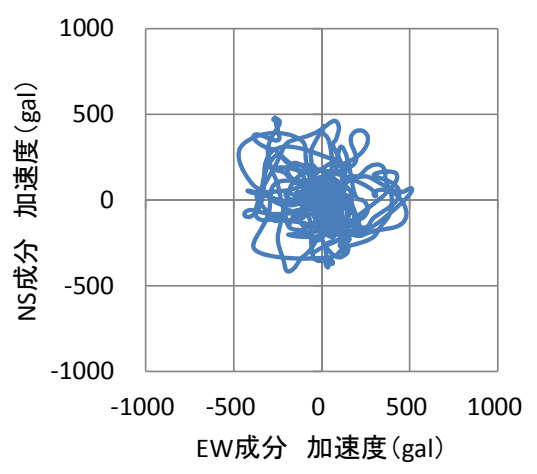

図-5 兵庫県南部地震 JR鷹取駅観測波の 2 方向応答スペクトル適合波

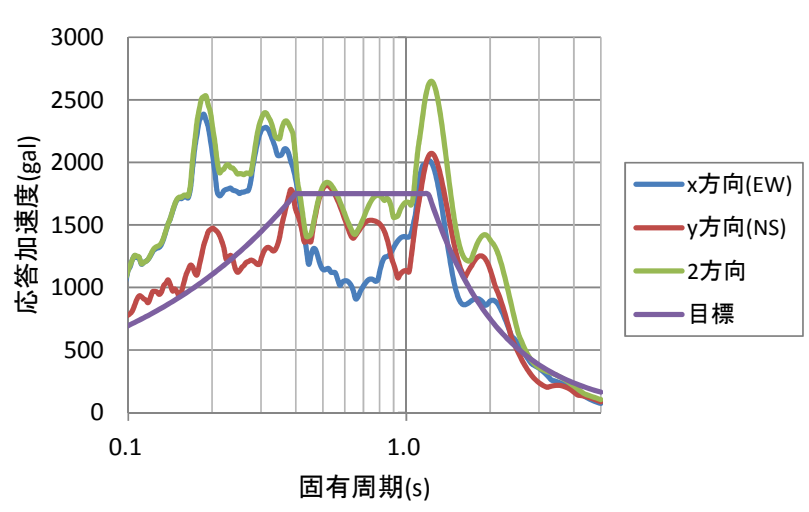

図-6 兵庫県南部地震 JR鷹取駅観測波の 応答スペクトル (スペクトル適合前)

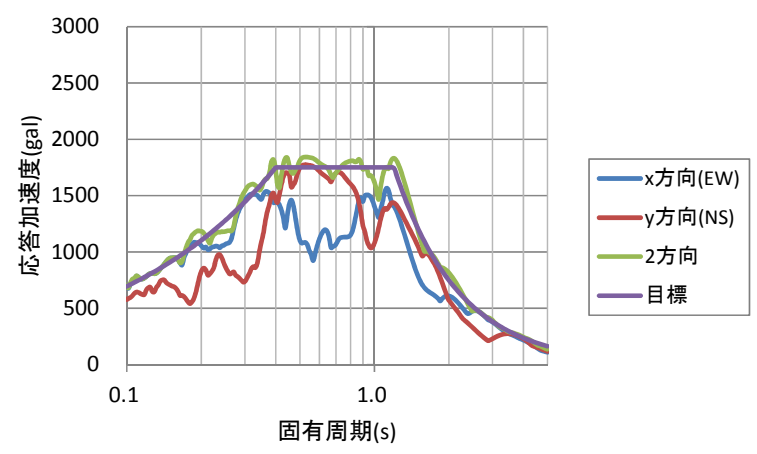

図-7 兵庫県南部地震 JR鷹取駅観測波の

応答スペクトル（スペクトル適合後）

$$
\begin{aligned}
& A_{\text {new_k }}=A_{k} / \gamma_{R k} \\
& B_{\text {new_k }}=B_{k} / \gamma_{R k}
\end{aligned}
$$

$k=1$ ～N/2-1 までのある振動数 $f_{k}$ の単振動の単振動は

$$
\begin{aligned}
& x_{\text {new } k}(t)=A_{\text {new } k} \cos \left(2 \pi f_{k} t+\phi_{x_{-} k}\right) \\
& y_{\text {new }_{-} k}(t)=B_{\text {new }_{-} k} \cos \left(2 \pi f_{k} t+\phi_{y_{-} k}\right)
\end{aligned}
$$

となり, 式(18), 式(19)の処理をスペクトル適合度を満足 するまで繰り返す.

この手法における作成例として，1995 年兵庫県南部 地震における JR 鷹取駅構内地盤上観測波を原波として, 道路橋示方書のレベル 2 地震動タイプ II の II 種地盤の標 準加速度応答スペクトル $S_{\text {II0 }}{ }^{10)}$ を目標とする 2 方向応答ス ペクトルとした. 応答スペクトルの適合条件は，原子力

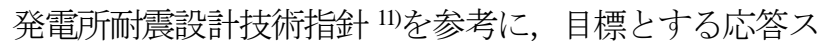
ペクトルとの比の最小值が 0.85 以上であること, 目標 とする応答スペクトルとの SI 比が 1.0 以上あることを判 定基準とした. 図-4 に本計算例の原波である兵庫県南 部地震 JR 鷹取駅観測波の加速度軌跡を, 図-5 に提案し た手法による 2 方向スペクトル適合波の加速度軌跡を示 す.また，兵庫県南部地震 JR 鷹取駅観測波のスペクト ル適合前後の応答スペクトルを図-6, 図-7 にそれぞれ示 す. 図-6, 図-7 に示すように，2 方向応答スペクトルの 形状が変化し，最終的には良好な適合がなされているこ とが確認できる.

\section{（4）加速度軌跡の異なる2方向応答スペクトル適合波}

道路橋示方書 ${ }^{10)}$ に示されるレベル 2 地震のタイプ II の II 種地盤の兵庫県南部地震 JR鷹取駅構内地盤上 NS 成分 の振幅調整波（以下，II-II-1 波）とその応答スペクトル を基本とし，同一の 2 方向応答スペクトルに適合する 4 ケースの入力地震動を表-1 に示す. この 4 ケースの地震 動を 3 章，4 章，5 章の検討で用いる 2 方向入力とする. 図-8 から図-11 に各ケースの加速度軌跡を, 図-12 に各 ケースの 2 方向加速度応答スペクトルを, 図-13 に各ケ 一スの 2 方向変位応答スペクトルを重社書きした図を示 す. 図-12, 図-13 に示されるように，各ケースの 2 方向 
応答スペクトルはほぼ等しいことがわかる。また，図14 から図-17 に各ケースにおける水平直交 2 成分の応答 スペクトルと 2 方向応答スペクトルを示す.

表-1 入力地震動のケース一覧

\begin{tabular}{|c|c|c|c|c|}
\hline ケース & $\begin{array}{l}\text { 入力の } \\
\text { 加速度 } \\
\text { 軌跡 }\end{array}$ & 成分 & 地震動 & $\begin{array}{l}\text { 振幅 } \\
\text { 倍率 }\end{array}$ \\
\hline \multirow{2}{*}{ Case 1} & \multirow{2}{*}{$\begin{array}{l}\text { 斜め } \\
\text { 入斜 }\end{array}$} & $x$ & II-II-1波 & $1 / \sqrt{2}$ \\
\hline & & $y$ & II-II-1波 & $1 / \sqrt{2}$ \\
\hline \multirow[b]{2}{*}{ Case $2^{5)}$} & \multirow[b]{2}{*}{ 円形 } & $x$ & II-II-1波 & 1.0 \\
\hline & & $y$ & $\begin{array}{c}\text { II-II-1波の } \\
\text { 相補直交成分波 } \\
\text { (ヒルベルト変換波) }\end{array}$ & 1.0 \\
\hline \multirow[b]{2}{*}{ Case $^{6)}$} & \multirow[b]{2}{*}{ 楕円形 } & $x$ & II-II-1波 & 1.0 \\
\hline & & $y$ & $\begin{array}{c}\text { II-II-1波の } \\
\text { 相補直交成分波 } \\
\text { (ヒルベルト変換波) }\end{array}$ & 0.3 \\
\hline \multirow{2}{*}{ Case 4} & \multirow{2}{*}{ 実位相 } & $x$ & $\begin{array}{c}\text { JR鷹取駅観測波 } \\
\text { EW成分の振幅調整波 }\end{array}$ & 1.0 \\
\hline & & $y$ & $\begin{array}{c}\text { JR鷹取駅観測波 } \\
\text { NS成分の振幅調整波 }\end{array}$ & 1.0 \\
\hline
\end{tabular}

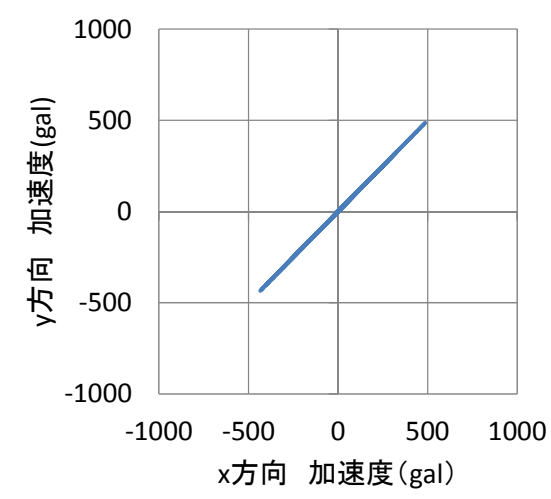

図-8 Case1（斜め入射）の加速度軌跡

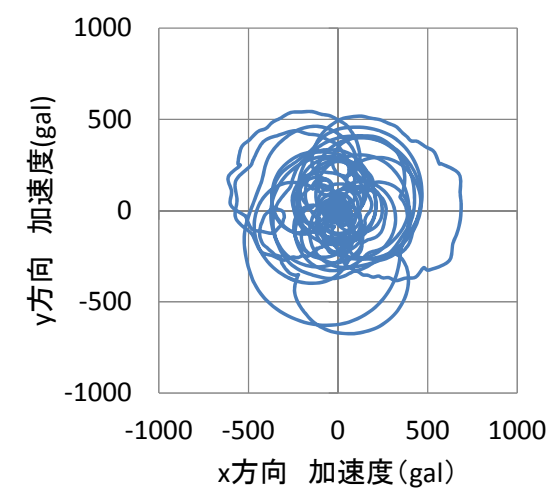

図-9 Case2 (円形軌跡) の加速度軌跡

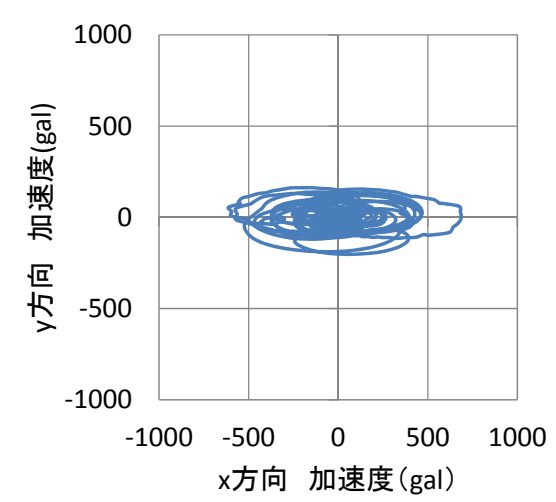

図-10 Case3（楕円形軌跡）の加速度軌跡

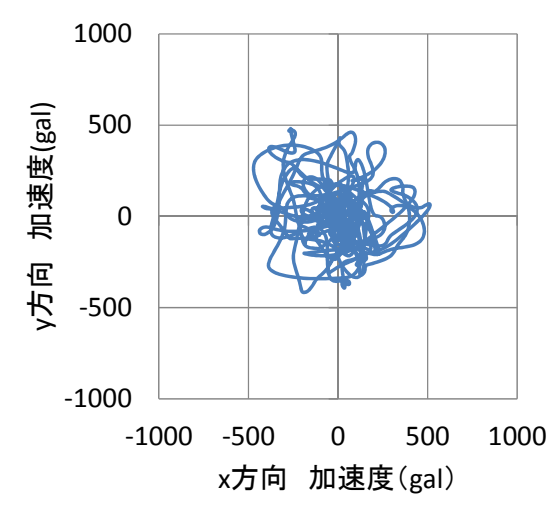

図-11 Case4（実位相）の加速度軌跡

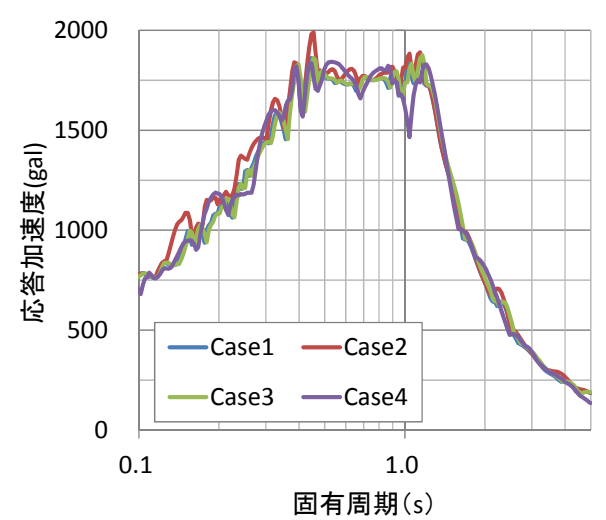

図-12 各ケースの 2 方向加速度応答スペクトル

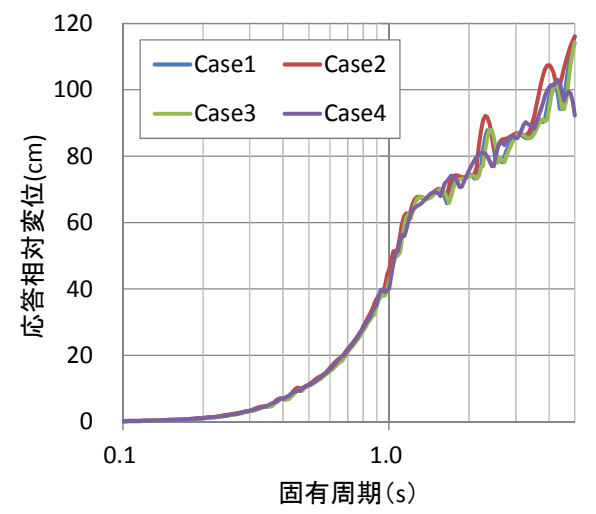

図-13 各ケースの 2 方向変位応答スペクトル 


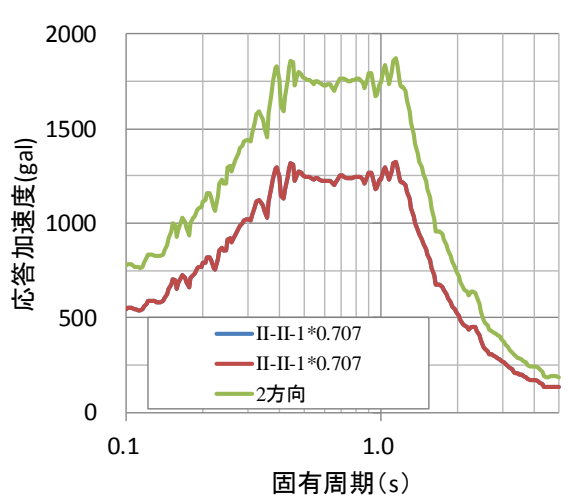

図-14 Case1（斜め入射）の応答スペクトル

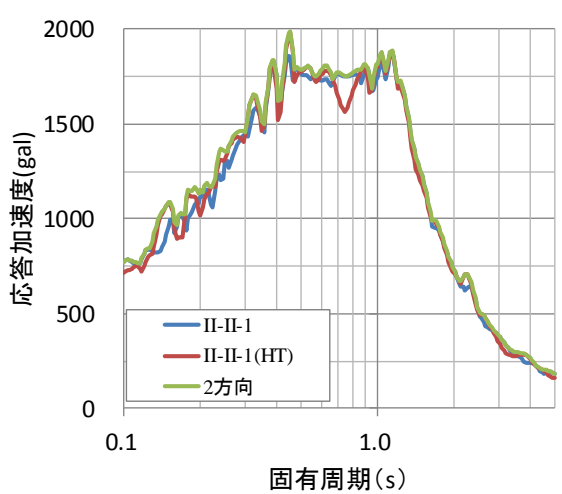

図-15Ｃase2（円形軌跡）の応答スペクトル

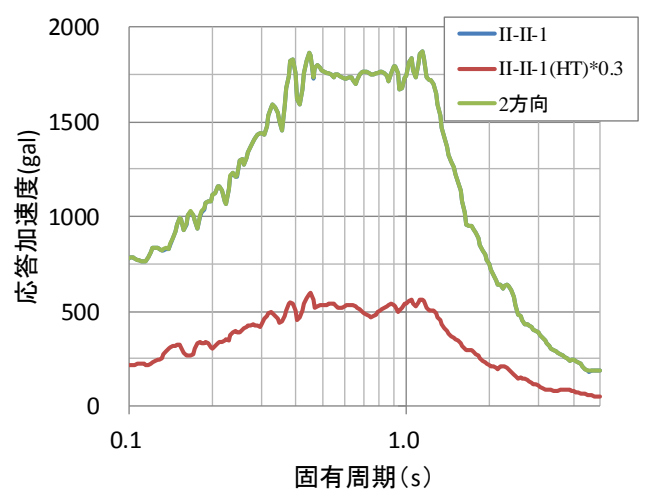

図-16 Case3（楕円軌跡）の応答スペクトル

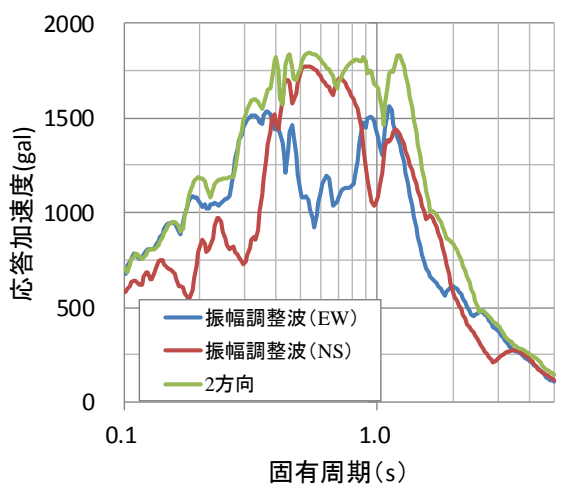

図-17 Case4（実位相）の応答スペクトル

\section{2方向エネルギースペクトルによる2方向応答 スペクトル適合波の評価}

(1) エネルギースペクトル

エネルギースペクトルとは，1 質点弾性減衰系への入 力エネルギーE の速度換算值 $V_{E}$ を各固有周期に対して 求めたものである.

$$
V_{E}=\sqrt{2 E / m}
$$

\section{ここに， $E$ : 入力エネルギー， $m$ : 質点質量}

構造物への入力エネルギーは構造物の復元力特性，質 量分布や剛性分布の影響を受けず，主に構造物の総重量 や固有周期に依存することが知られている．具体的な算 出方法として, 1 次元線形弾性 1 質点振動子を対象にし た運動方程式を式(23)とすると，

$$
m \ddot{x}+c \dot{x}+f(x)=-m \ddot{x}_{0}
$$

ここに, $c \dot{x}$ : 減衰力, $f(x)$ : 復元力,

$-m \ddot{x}_{0}:$ 地震力, $x_{0}:$ 水平地動,

$x:$ 質点の地面に対する相対変位

式(23)の両辺に，相対変位増分 $d x=\dot{x} d t$ を乗じて地震 動の継続時間 t 0 に渡って積分すると，エネルギーの釣り 合い式となり，式(24)のように表される.

$$
\begin{aligned}
& m \int_{0}^{t_{0}} \ddot{x} \dot{x} d t+c \int_{0}^{t_{0}} \dot{x} \dot{x} d t+\int_{0}^{t_{0}} f(x) \dot{x} d t \\
& =-m \int_{0}^{t_{0}} \ddot{x}_{0} \dot{x} d t
\end{aligned}
$$

式(24)の左辺の第一項目からそれぞれ，弾性振動エネ ルギー，減衰によるエネルギー吸収量，累積塑性ひずみ エネルギーであり，これらの和が右辺である入力エネル ギーEと等しいというものである.

$$
E=-m \int_{0}^{t_{0}} \ddot{x}_{0} \dot{x} d t
$$

固有周期 $T$ としたときの, 応答速度時刻歴 $\dot{x}(=d x / d t)$ を算出し, 入力加速度 $\ddot{x}_{0}$ との積を $d t$ で積 分すると, 固有周期ごとに総エネルギー入力が算出され, これを総エネルギー換算速度に置き換えることにより， 速度の次元を持つエネルギースペクトルを算出すること ができる.

\section{（2） 2 方向エネルギースペクトル}

水平面を $x-y$ 座標系で定義した場合の 2 次元線形弾 性 1 質点振動子に水平 2 方向入力をした際の運動方程式 は，式(26)のように表すことが出来る.

$$
\begin{gathered}
M \frac{d^{2} \mathbf{r}}{d t^{2}}+C \frac{d \mathbf{r}}{d t}+\mathbf{F}=-M \ddot{\mathbf{r}}_{0} \\
M=\left(\begin{array}{cc}
m & 0 \\
0 & m
\end{array}\right), C=\left(\begin{array}{ll}
c & 0 \\
0 & c
\end{array}\right), \mathbf{F}=\left(\begin{array}{l}
f_{x} \\
f_{y}
\end{array}\right)
\end{gathered}
$$




$$
\ddot{\mathbf{r}}_{0}=\left(\begin{array}{c}
\ddot{x}_{0} \\
\ddot{y}_{0}
\end{array}\right), \quad \mathbf{r}=x \mathbf{e}_{x}+y \mathbf{e}_{y}
$$

$M$ : 質量マトリックス, $C$ : 減衰マトリックス,

$\mathbf{F}:$ 復元力ベクトル, $\mathbf{r}_{0}:$ 水平地動ベクトル

$\mathbf{r}$ : 位置ベクトル, $\mathbf{e}_{x}, \mathbf{e}_{y}$ : 単位ベクトル

である。

1 次元のエネルギースペクトルの算出過程と同様に, 式(26)の両辺に相対変位増分ベクトル $d \mathbf{r}=\dot{\mathbf{r}} d t$ を乗じ て地震動の継続時間 $t_{0}$ に渡って積分すると, 2 次元の工 ネルギーの釣り合い式となり，式(27)のように表される.

$$
\begin{aligned}
& m \int_{0}^{t_{0}} \frac{d^{2} \mathbf{r}}{d t^{2}} \cdot \frac{d \mathbf{r}}{d t} d t+c \int_{0}^{t_{0}} \frac{d \mathbf{r}}{d t} \cdot \frac{d \mathbf{r}}{d t} d t+\int_{0}^{t_{0}} \mathbf{F} \cdot \frac{d \mathbf{r}}{d t} d t \\
& =-m \int_{0}^{t_{0}} \ddot{\mathbf{r}}_{0} \cdot \frac{d \mathbf{r}}{d t} d t
\end{aligned}
$$

式(27)の右辺に着目して $x$ 成分と $y$ 成分で表記すると

$$
\begin{gathered}
-m \int_{0}^{t_{0}} \mathbf{r}_{0} \cdot \frac{d \mathbf{r}}{d t} d t \\
=-m \int_{0}^{t_{0}}\left(\ddot{x}_{0} \dot{x}+\ddot{y}_{0} \dot{y}\right) d t \\
=-m \int_{0}^{t_{0}} \ddot{x}_{0} \dot{x} d t-m \int_{0}^{t_{0}} \ddot{y}_{0} \dot{y} d t \\
E_{x}=-m \int_{0}^{t_{0}} \ddot{x}_{0} \dot{x} d t \\
E_{y}=-m \int_{0}^{t_{0}} \ddot{y}_{0} \dot{y} d t
\end{gathered}
$$

とすると， 2 次元性を考慮した全入力エネルギ一は，式 (31)に示すように, $x$ 方向と $y$ 方向の入力エネルギーの和 で示すことが出来る.

$$
E=E_{x}+E_{y}
$$

1 次元の場合と同様に 2 次元のエネルギースペクトルを 換算速度で表すと

$$
V_{E}=\sqrt{2 E / M}=\sqrt{\frac{2\left(E_{x}+E_{y}\right)}{M}}
$$

となる. 図-18に 2.(4)の 4 ケースの 2 方向入力に対して, 式(32)で算出した 2 方向エネルギースペクトルを示す. なお， 2 方向エネルギースペクトルを算出する際の減衰 定数は $10 \%$ とした ${ }^{12)}$. 2 方向応答スペクトルが同一であ っても, 加速度軌跡の違い, $x$ 方向と $y$ 方向の両成

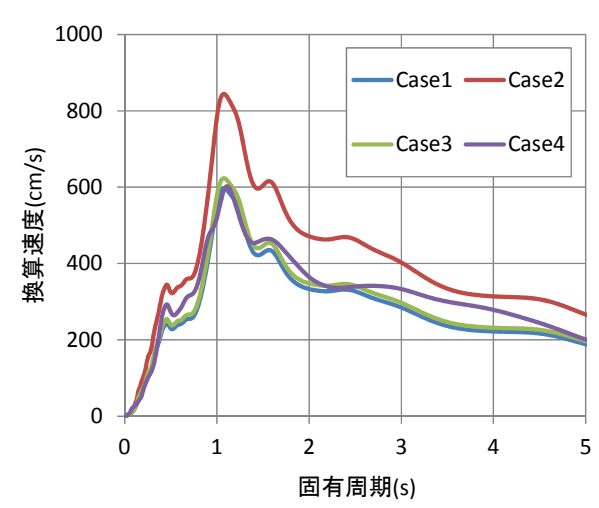

図-18＼cjkstart各ケースの2方向エネルギースペクトル
分の入力加速度が大きいこと, また, それに伴う応答速 度が大きいことにより， Case 2 の入力エネルギーは，他 のケースに比べて大きいことがわかる.

\section{4. 水平2方向地震動の軌跡特性がMSSモデルの弾 塑性応答に及ぼす影響}

\section{(1) 解析条件}

対象とする解析モデルは，構造物の水平 2 方向の応答 特性を評価するために，8本のせん断ばねで構成された MSS(Multi Shear Spring )モデルによる簡便な1質点系モデ ルとした。図-19にMSSモデルの概要図を示す。表-2に 示すような弾性固有周期の異なる 3 種類の解析モデルを 設定した。なお，MSSモデルは，図-20に示すようなバ イリニア型の履歴特性を有するばねを等間隔に配置する ことで，水平2方向の非線形応答に相関性を持たせるこ とができる，本検討のように各ばねを図-20に示すバイ リニア型でモデル化すると, 複数のばねの降伏するタイ ミングが異なることでMSSモデルの全体挙動としては図 -21に示すような明確な降伏点を持たない復元力特性と なる，本検討では，MSSモデルを構成するのせん断ばね は二次剛性比0.05のバイリニア型の弾塑性モデルとした. また，本検討で用いたMSSモデルは並進のみの自由度を 有するため, MSSモデルを構成するばねを弾性モデルと すると，2方向応答スペクトルを算出するモデルと一致 する. 本検討に用いるモデルのパラメーターは参考文献 6)を参考に設定した. MSSモデルの諸元を表-2に示す. 入力地震動は，2.(4)に示されるCase1からCase4の4ケース の水平 2 方向入力とした. また, 地震動入力の振幅を 徐々に増加させながら非線形動的解析を行う漸増動的解 析 ${ }^{13)}$ (IDA, Incremental Dynamic Analysis) を行い, 各入力 地震動ケースにおける最大応答変位に関するIDA曲線 （横軸に最大応答変位, 縦軸に振幅倍率（S.F））を作 成した。

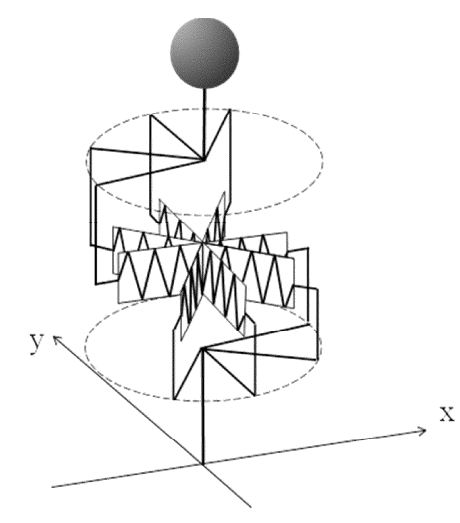

図-19ＭSS モデルの概要図 
表-2ＭSS モデルの諸元

\begin{tabular}{|c|c|c|c|}
\hline 質量 $(\mathrm{t})$ & \multicolumn{3}{|c|}{50} \\
\hline 重量 $(\mathrm{kN})$ & \multicolumn{3}{|c|}{490.5} \\
\hline 降伏力 $(\mathrm{kN})$ & \multicolumn{3}{|c|}{0.05 .3} \\
\hline 隇衰 & \multicolumn{3}{|c|}{0.05} \\
\hline 2次剛性比 & \multicolumn{3}{|c|}{} \\
\hline 弾性固有周期 $T(\mathrm{~s})$ & 0.4 & 1.0 & 1.8 \\
\hline 初期剛性 $(\mathrm{kN} / \mathrm{m})$ & 12337 & 1974 & 609 \\
\hline 降伏変位 $(\mathrm{mm})$ & 19.9 & 124.2 & 402.6 \\
\hline
\end{tabular}

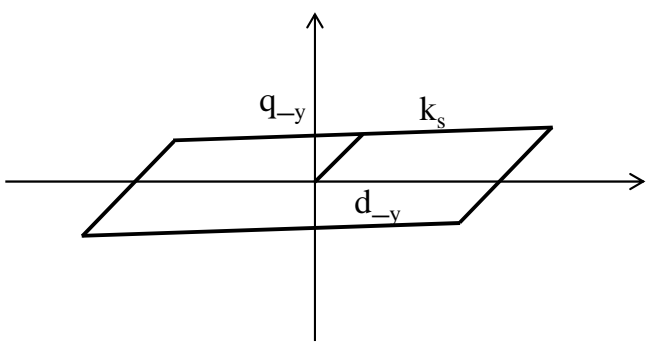

図-20ＭSS モデルの構成する各せん断ばねの荷重-変位関係

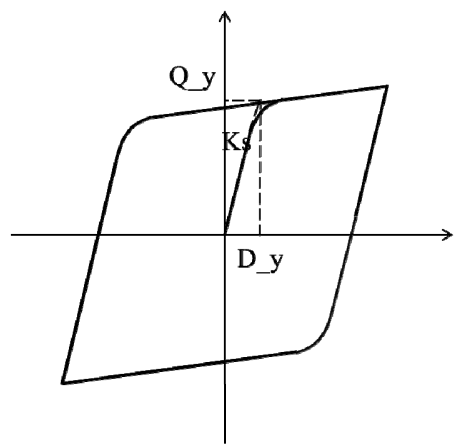

図-21ＭSSモデル全体の荷重-变位関係

\section{（2）解析結果}

表-3に解析結果として，各ケースの最大応答変位を示 す. 各ケースの 2 方向入力が同一の 2 方向応答スペクトル に適合しているため，MSSモデルを弾性とした場合の最 大応答変位は，ほぼ同一の值となっている．MSSモデル を弾塑性モデルとした場合の最大応答変位は，各ケース で最大応答が異なり，いずれの弾性固有周期の場合でも Case2（円形軌跡）を入力とした場合が最大応答変位が 大きい結果となった.

図-22から図-25に弾性固有周期1.0秒とした場合の弾性, 弾塑性モデルに対する応答変位軌跡を示す．MSSモデ ルを弾性，弾塑性モデルとした場合で，応答変位軌跡の 特徵が異なることがわかる.

また，図-26から図-28に各弾性固有周期に対する最大 応答变位のIDA曲線を示寸，最大応答変位が降伏変位以 下となる振幅レベルでは，弾性挙動のため最大态答変位 が各地震動ケースごとで等しい，最大応答変位が降伏変 位以上となる振幅レベルでは，各ケースの最大応答変位 のIDA曲線が交差することも見られるが，おおむねCase2
の円形軌跡を入力とした場合に，最大応答変位が最大と なる傾向が見られた。これは，3.(2)で示した各ケースの 2方向エネルギー応答スペクトルの大小関係が，最大応 答変位の傾向として表れている．また，弾性固有周期 1.0秒のモデルにおいて，振幅倍率1.5以上の範囲に着目 すると，Case2よりもCase 1やCase3の最大応答変位が大き くなる傾向が見られる。これについては，水平2方向入 力による2方向弾塑性挙動の更なる分析が必要と考えら れる．ただし，危機而性の観点から見れば，2方向入力 による漸増動的解析による而震設計・照査の必要性が示 される結果となった.

表-3 最大応答変位一覧

\begin{tabular}{|c|c|c|c|c|c|}
\hline \multirow[b]{2}{*}{ ケース } & \multirow[b]{2}{*}{$\begin{array}{c}\text { 入力の } \\
\text { 加速度 } \\
\text { 軌跡 }\end{array}$} & \multirow[b]{2}{*}{$\begin{array}{l}\text { 構造 } \\
\text { モデル }\end{array}$} & \multicolumn{3}{|c|}{ 最大応答変位（cm） } \\
\hline & & & $\begin{array}{c}\text { 弾性 } \\
\text { 固有 } \\
\text { 周期 } \\
0.4 \\
\text { (sec) }\end{array}$ & $\begin{array}{c}\text { 弾性 } \\
\text { 固有 } \\
\text { 周期 } \\
1.0 \\
\text { (sec) }\end{array}$ & $\begin{array}{c}\text { 弾性 } \\
\text { 固有 } \\
\text { 周期 } \\
1.8 \\
\text { (sec) }\end{array}$ \\
\hline \multirow{2}{*}{ Case1 } & \multirow{2}{*}{$\begin{array}{l}\text { 斜め } \\
\text { 入射 }\end{array}$} & 弾性 & 7.0 & 44.0 & 73.0 \\
\hline & & 弾塑性 & 7.3 & 43.1 & 59.1 \\
\hline \multirow{2}{*}{ Case2 } & \multirow{2}{*}{ 円形 } & 弾性 & 7.1 & 45.8 & 74.2 \\
\hline & & 弾塑性 & 10.0 & 50.8 & 81.0 \\
\hline \multirow{2}{*}{ Case3 } & \multirow{2}{*}{ 楕円形 } & 弾性 & 7.0 & 44.0 & 73.0 \\
\hline & & 弾塑性 & 7.8 & 44.6 & 58.1 \\
\hline \multirow{2}{*}{ Case4 } & \multirow{2}{*}{ 実位相 } & 弾性 & 7.0 & 40.9 & 74.0 \\
\hline & & 弾塑性 & 6.2 & 39.1 & 67.1 \\
\hline
\end{tabular}

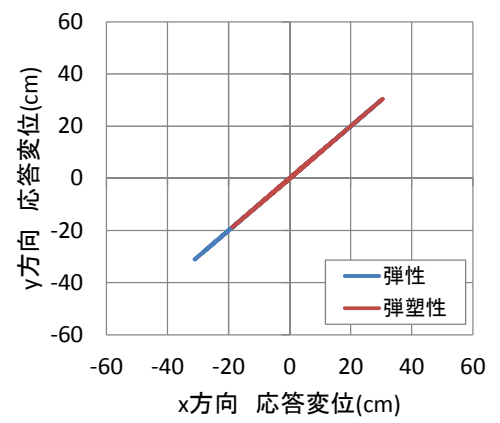

図-22 Case $1 の$ 応答変位軌跡 (弾性固有周期 : 1.0 秒)

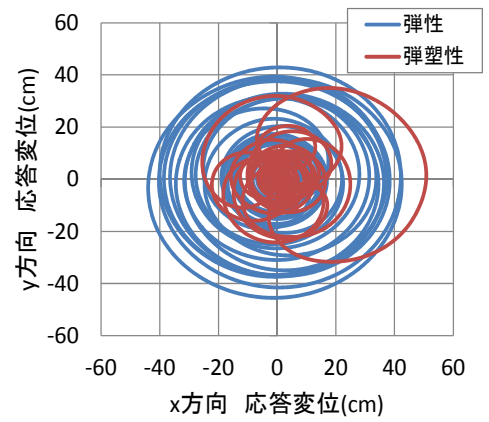

図-23 Case 2 の応答変位軌跡（弾性固有周期：1.0秒） 


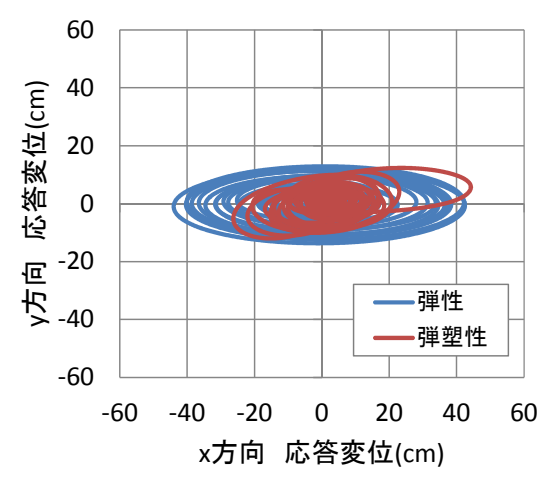

図-24 Case3の応答変位曲線（弾性固有周期：1.0秒）

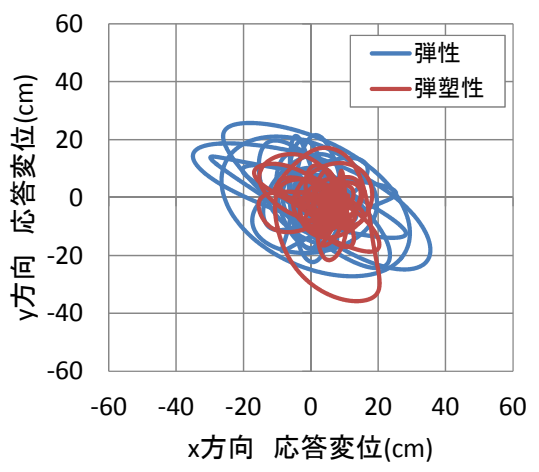

図-25 Case 4 の応答変位軌跡（弾性固有周期：1.0秒)

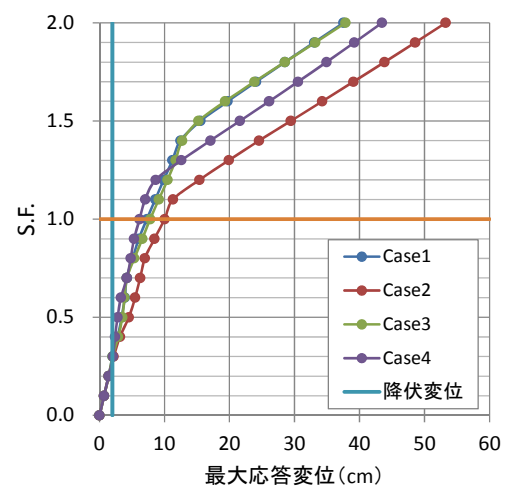

図-26 最大応答変位の IDA 曲線（弾性固有周期：0.4秒）

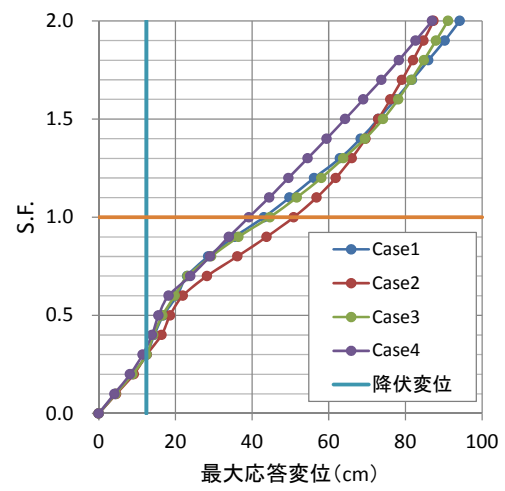

図-27 最大応答変位の IDA曲線（弾性固有周期：1.0秒）

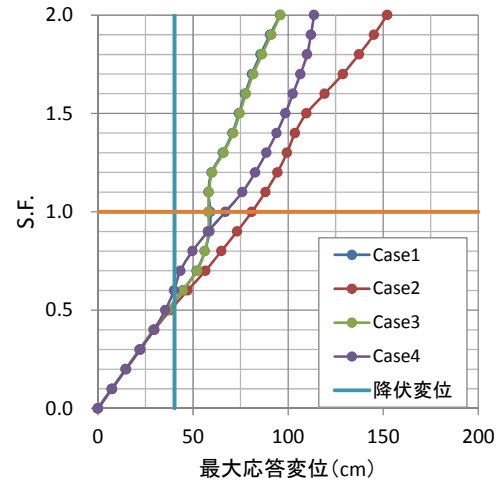

図-28 最大応答変位の IDA曲線（弾性固有周期 : 1.8 秒）

\section{5. 水平2方向地震動の軌跡特性がファイバ一モデ ルの弾塑性応答に及ぼす影響}

\section{(1) 解析条件}

解析モデルは，橋梁の上部構造と円形断面のRC橋脚 の1本柱を取り出したようなモデルを対象とする．モデ ル底面から上部構造を模擬した質点までをファイバー要 素と線形はり要素で合わせて10等分したモデルとし，そ

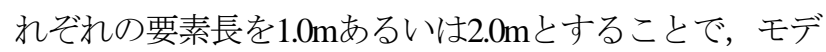
ルの高さが10mと20mとなる2ケースのモデルを対象とし た（図-29）。モデルはNEXCO三社の設計要領第二集橋 梁建設編14)を参考に，モデル下部のフーチングとモデル 上部析部は線形はり要素で剛域を設けた。 また, 塑性変 形が発生すると予想される橋脚基部をファイバー要素で モデル化をした．高さ10mと20mのモデルのそれぞれの モデルの弾性固有周期は約0.4秒, 約1.2秒である. ファ イバー要素部分は, 材料非線形を考慮し, コンクリート および鉄筋の非線形性を考慮している. ファイバー要素 部の断面分割を図-30に，本解析用に設定した物性值を 表-4に示す. RC断面の諸元は参考文献の15)を参考に設 定し， $2.0 \mathrm{~m}$ の形断面に，鉄筋は降伏強度 $345 \mathrm{~N} / \mathrm{mm}^{2}$ とし たD35の鉄筋を2段で36本ずつ，円周状に配置している. コンクリートの圧縮強度は30 $/ \mathrm{mm}^{2}$ とて, 圧縮側の応 カーひずみ曲線はコンクリート標準示方書設計編16を参考 に設定し，引張側の強度は見込んでいない. 鉄筋は，降 伏強度345N/mm² としたバイリニア型の応力-ひずみ関係 とし，降伏剛性は初期剛性の1/1000とした．解析に用い たコンクリートと鉄筋の応力-ひずみ関係をそれぞれ図31, 図-32に示寸。

なお，本モデル底面の境界条件は基礎固定しており， 逸散减衰が考慮されないため, 2.(4)で示寸水平2方向入 力をそのまま用いると, 構造モデルに対して非常に大き な入力となる. そこで, IDAにおける振幅倍率は0.1から 開始し，コンクリート圧壊直前となる振幅倍率 0.7 まで 実施した. 


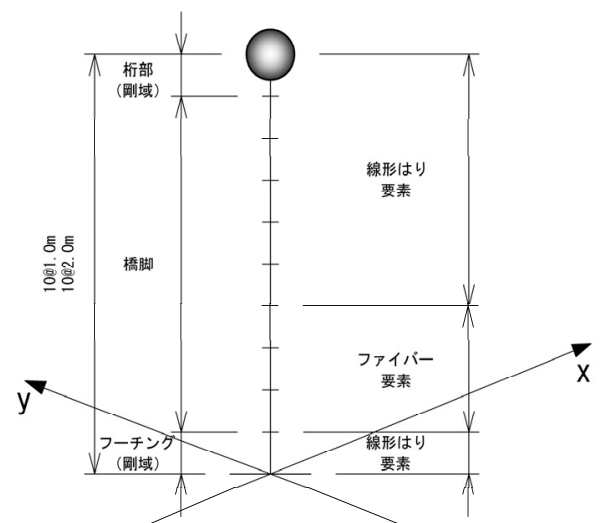

図-29 解析モデル

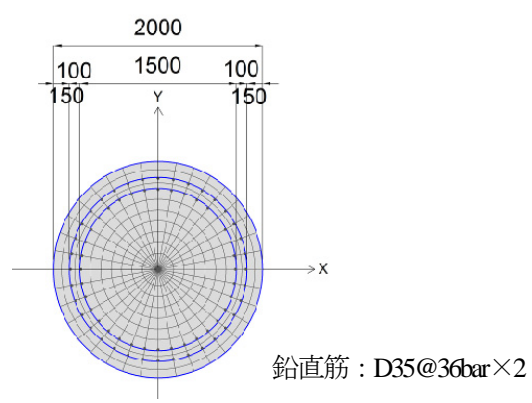

図-30 ファイバーモデル断面図

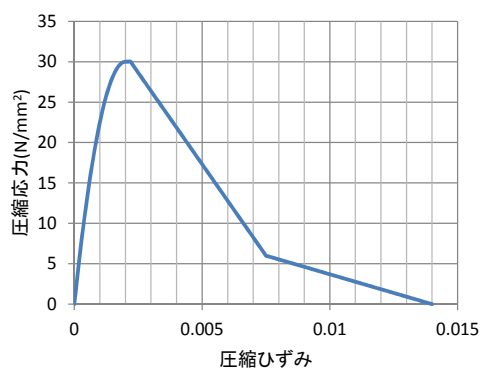

図-31 コンクリートの圧縮側の応力-ひずみ曲線

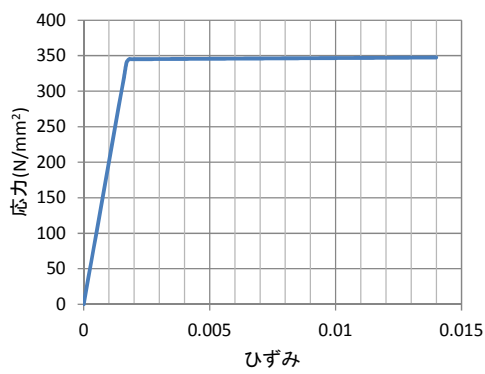

図-32 鉄筋の応力-ひずみ曲線

表-4 解析モデルの物性值

\begin{tabular}{|c|c|c|c|c|c|}
\hline 要素 & 材料/部材 & $\begin{array}{c}\text { 弹性係数 } \\
\left(\mathrm{kN} / \mathrm{m}^{2}\right)\end{array}$ & $\begin{array}{c}\text { ポアソン } \\
\text { 比 }\end{array}$ & $\begin{array}{c}\text { 単位 } \\
\left(\mathrm{kN} / \mathrm{m}^{3}\right)\end{array}$ & $\begin{array}{c}\text { 減衰 } \\
\text { 定数 }\end{array}$ \\
\hline \hline \multirow{2}{*}{$\begin{array}{c}\text { ファイバー } \\
\text { 要素 }\end{array}$} & コンクリート & $2.8 \times 10^{7}$ & 0.2 & 23 & 0.02 \\
\cline { 2 - 6 } & 鉄筋 & $2.0 \times 10^{8}$ & 0.3 & 77 & 0.02 \\
\hline $\begin{array}{c}\text { 線形はり } \\
\text { 要素 }\end{array}$ & 鉄筋コンクリート & $2.8 \times 10^{7}$ & 0.2 & 24.5 & 0.05 \\
\hline
\end{tabular}

\section{（2） 解析結果}

解析結果として，図-33，図-34に弾性固有周期0.4秒と 弾性固有周期1.2秒のモデルを対象に，弾性解析とした 場合の最大応答変位分布を示寸，同様に図-35，図-36に はそれぞれのモデルを弾塑性解析とした場合の最大応答 変位分布を示寸，RC橋脚を弾性体とした場合の最大応 答変位は，加速度軌跡の違いに依らず概ね等しい結果と なっている。一方，RC橋脚を弾塑性体とした場合， Case2 (円形軌跡) を入力とした場合の最大応答変位が大 きくなる結果となった.

また，図-37，図-38に弾性固有周期0.4秒と弾性固有周 期1.2秒のモデルを対象にしたコンクリートの最大圧縮 ひずみに関するIDA曲線を示す。コンクリートの圧縮ひ ずみが非線形化する振幅レベルにおいては，Case2（円 形軌跡）を入力した場合の応答が大きくなることが示さ れた. 水平2方向入力の加速度軌跡が構造物の弾塑性応 答に及ぼす影響の傾向として，MSSモデルのような並進 のみの自由度を有するモデルと同様に，本章で検討した 並進と回転の自由度を有するモデルに対しても，Case2 （円形軌跡）の入力が弾塑性応答に及ぼす影響が最も大 きいことが確認された。

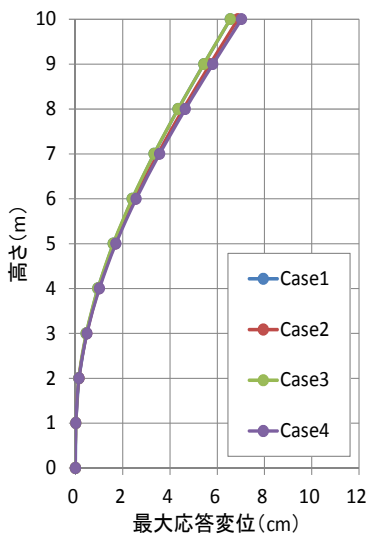

図-33 最大応答変位分布図 (弾性固有周期 0.4 秒 弾性モデル)

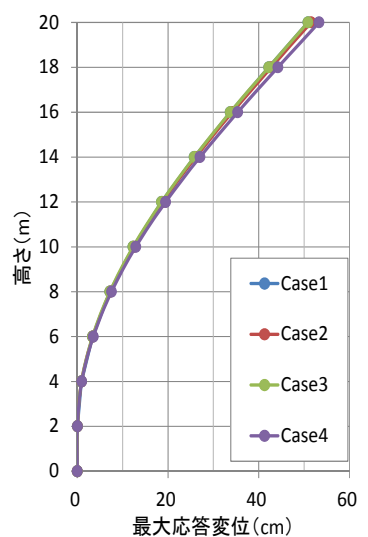

図-34 最大応答変位分布図 (弾性固有周期 1.2 秒 弾性モデル) 


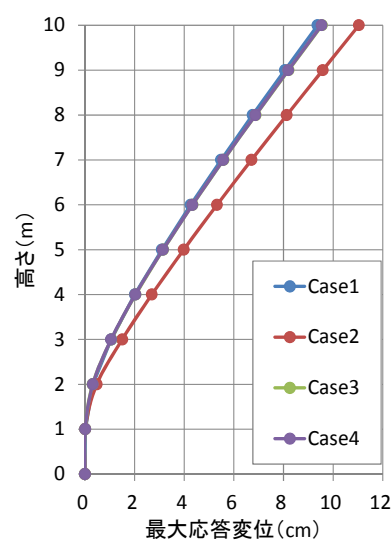

図-35 最大応答変位分布図 (弾性固有周期 0.4 秒 弾塑性モデル)

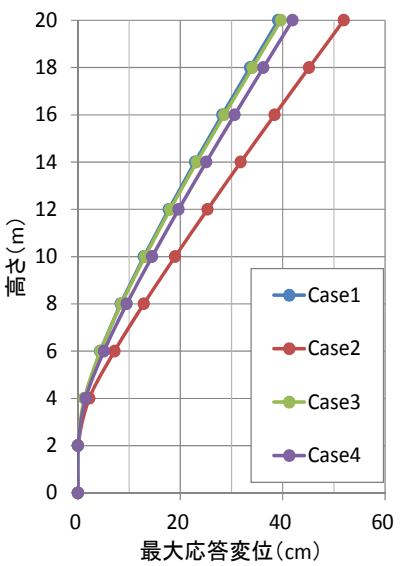

図-36 最大応答変位分布図 (弾性固有周期 1.2 秒 弾塑性モデル)

\section{6. 結論}

本研究は, 3次元地震応答解析よる耐震設計・耐震性 能照査において，2方向応答スペクトルに適合した水平2 方向地震動の合理的な設定法の提案を目的に，水平 2 方 向地震動の加速度軌跡が構造物の弾塑性応答に及ぼす影 響の検討を行った．本研究を通じて得られた知見は以下 の通りである.

1) 従来の1次元の振幅調整によるスペクトル適合法 を，2次元に拡張したスペクトル適合法を提案し， 観測記録の位相特性を有した加速度軌跡の2方向応 答スペクトル適合波の作成法を提案した，本論文で は1995年兵庫県南部地震のJR鷹取駅での観測波の一 例を示したが，他の観測記録にも適用できる有効な 手法である.

2）地震動の構造物への入力エネルギーを評価できる エネルギースペクトルを従来の1次元から2次元に拡 張し，水平2方向エネルギースペクトルを提案した. この指標を用いることで，同一の2方向応答スペク

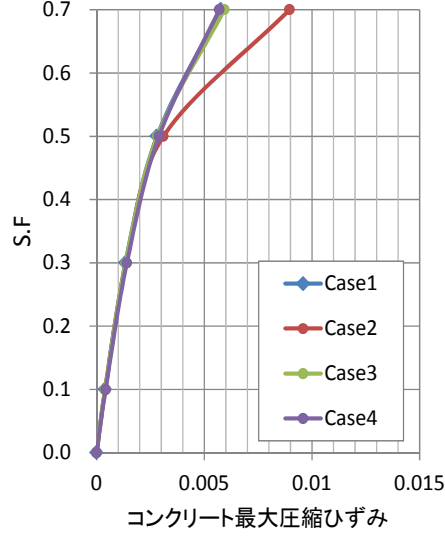

図-37 コンクリート最大圧縮ひずみの IDA曲線 (弾性固有周期 0.4 秒 弾塑性モデル)

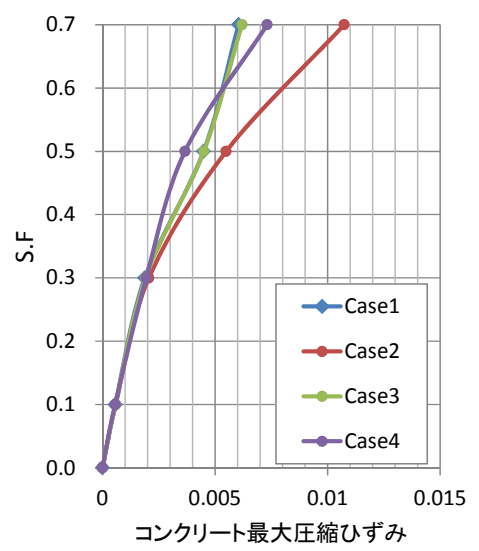

図-38 コンクリート最大圧縮ひずみの IDA 曲線 (弾性固有周期 1.2 秒 弾塑性モデル)

ルを従来の1次元から2次元に拡張し，水平2方向工 ネルギースペクトルを提案した. この指標を用いる ことで，同一の2方向応答スペクトルに適合した水 平2方向入力でも, 加速度軌跡によって2方向エネル ギースペクトルが異なることを示した，特に，標準 波-相補直交成分波（ヒルベルト変換波）のような 円形軌跡の場合に，他の加速度軌跡に比べて，2方 向エネルギースペクトルは大きくなることが明らか になった。

3）簡易なMSSモデルとより実挙動を模擬できるファ イバーモデルを用い，水平 2 方向入力の加速度軌跡 の違いが弾塑性応答に及ぼす影響について検討した。 いずれのモデルによる比較解析においても，標準波 -相補直交成分波（ヒルベルト変換波）のような円 形軌跡が他の加速度軌跡よりも弾塑性応答が大きく なる傾向となった．ただし，漸増動的解析の結果に よると，振幅レベルによっては，必ずしも円形軌跡 を入力とした場合に最大応答変位が最大とならない 結果も示された．また，地震動レベルによって地震 応答の傾向が変化することは，危機而性の観点から 
見れば，水平2方向入力による漸増動的解析の必要 性が示された.

また，今後の課題を以下に示す.

1）今回の水平2方向地震動の検討結果は，1995年兵 庫県南部地震のJR鷹取駅での観測波のみを対象にし たものである．今後は地震タイプの異なる継続時間 の長い海洋型地震動や他の観測地震動を対象にした 検討も行う必要があると考えられる。

2) 今回の研究で対象とした構造モデルは線形弾性時 に等方なモデルであり，かつ幾何的にも対称構造で ある．今後は，幾何的に非対称であり，㸚じれモー ドが生じるような構造モデルを対象に2方向入力に よる検討を行う必要があると考えられる.

3）振幅レベルによって, 最大応答が最大となる加速 度軌跡が異なる結果となった．複雑な弹塑性応答に ついてより詳細に分析する必要がある.

\section{参考文献}

1) 本間俊介, 藤田航平, 市村強, 堀宗朗, Seckin CITAK, 堀高峰: 断層-都市系のパラメータの不確実 性を考慮可能な統合地震シミュレータの開発，土木 学会論文集 A1（構造・地震）, Vol. 70, No. 4, pp.I_199-I_209, 2014.

2) 藤田航平, 市村強, 堀宗朗, M. L. L. Wijerathne, 田中 聖三 : 多数の地震シナリオに対する高分解能な都市 震災想定のための HPC による基礎検討, 土木学会論 文集 A2 (応用力学)，Vol. 69, No. 2, pp. I_415-I_424, 2013.

3) 荻本英典, 川島一彦, 渡邊学歩, 永田聖二 : 水平 2 方向地震力の同時作用が RC 単柱式橋脚の耐震性に及 ぼす影響, 土木学会論文集, No. 801/I-73, pp. 33-50, 2005.

4) 党紀, 中村太郎, 青木徹彦, 鈴木森晶: 正方形断面 鋼製橋脚の水平 2 方向載荷ハイブリッド実験, 土木 学会構造工学論文集, Vol. 56A, pp. 367-380, 2010.

5) 五十嵐晃, 井上和真, 古川愛子, 宇野裕惠, 松田 宏 : 標準波-相補直交成分波の組合せによる橋梁の耐 震照查用水平 2 方向入力地震動, 土木学会論文集 $\mathrm{A} 1$

（構造・地震工学），Vol. 68, pp. I_458-I_469, 2012.

6) Igarashi, A. and Gigyu, S. : Synthesis of spectrumcompatible bidirectional seismic accelerograms with target elliptical component of polarization, Earthquake Resistant Engineering Structures $X$, WIT Transactions on The Built Environment, Vol. 152, pp. 63-72, DOI : 10.2495/ERES
150051, 2015.

7) 井上和真, 渡辺和明, 五十嵐晃, 畑明仁 : 強震動の 観測記録の水平 2 方向特性の分析と水平 2 方向応答 スペクトルに適合する入力地震動の作成法の提案, 土木学会論文集 A1（構造・地震工学）, Vol. 74, pp. I_555-I_568, 2016.

8) 秋山宏 : エネルギーの釣合に基づく建築物の耐震設 計，技報堂出版，1999.

9) 日本道路協会 : 道路橋示方書 - 同解説 $V$ 而震設計編, 丸善, 2002.

10) 日本道路協会 : 道路橋示方書 - 同解説 $V$ 耐震設計編, 丸善, 2012.

11) 日本電気協会：原子力発電所耐震設計技術指針, JEAG4601-2015.

12) 内藤伸幸, 松田泰治, 大塚久哲 : 地震入力エネルギ 一に基づく模擬地震波の作成について，第 26 回地震 工学研究発表会講演論文集, pp1149-1152, 2001.

13) 谷口惺, 五十嵐晃, 木田秀人 : 漸増動的解析(IDA)に 基づく長大橋の耐震性能評価, 土木学会論文集 A1 (構造・地震工学)，Vol. 70, No. 4, pp.I_323-I333, 2014.

14）東日本高速道路株式会社，中日本高速道路株式会社, 西日本高速道路株式会社：設計要領第二集 橋梁建設 編，高速道路総合技術研究所，2015.7.

15）右近大道, 梶原浩一, 川島一彦, 佐々木智大, 運上 茂樹, 堺淳一, 高橋良和, 幸左賢二, 矢部正明, 松 崎裕：EDefense を用いた実大 RC 橋脚(C1-5 橋脚)震動 破壊実験研究報告一現在の技術基準で設計した RC 橋 脚の耐震性に関する震動台実験およびその解析一, 防災科学技術研究所研究資料, 第 369 号, 2012.10.

16) 土木学会：コンククリート標準示方書（設計編）, 2012.

17) 日本道路協会 : 道路橋示方書 - 同解説 $V$ 而震設計編 に関する参考資料，丸善，2015.

18) 日本建築学会: 多次元入力地震動と構造物の応答, 丸善出版, 1998.

19）下村修一, 安達俊夫, 酒句教明 : エネルギーの釣合 に基づく地盤の地震時挙動の評価に関する研究一飽 和砂地盤の損傷程度及び入力エネルギーの評価一, 日本建築学会構造系論文集, 第 75 巻, 第 650 号, pp. 807-815, 2010.4.

20) 井上和真, 渡辺和明, 五十嵐晃 : 水平 2 方向入力の 加速度軌跡が構造物モデルの非線形応答に及ぼす影 響, 土木学会第 71 回年次学術講演会講演概要集, No.I-175, 2016.

(2016. 11. 2 受付, 2016. 12. 27 修正, 2017. 2. 18 受理) 


\section{EFFECT OF PARTICLE ORBIT CHARACTERISTICS ON ELASTIC-PLASTIC SEISMIC RESPONSE OF STRUCTURAL MODELS}

\section{Kazuma INOUE, Kazuaki WATANABE and Akira IGARASHI}

In this paper, the difference of orbit characteristics of bi-directional input waves affecting the elasticplastic response of structural models is investigated. The proposed method extends conventional 1D spectrum-compatible method to 2D, and shows how to match the random trajectory time histories, which is orthogonal in the horizontal plane, with the target bi-axial response spectrum. By extending the energy spectrum which represents the energy of input seismic motion, the concept of bi-axial energy spectrum is proposed. Using this spectrum, differences in input seismic energy is shown when acceleration trajectories of the waves vary. In addition, incremental dynamic analysis (IDA) was carried out for elasto-plastic structural model, causing excitation by bi-axial response spectrum-compatible accelerograms with different acceleration trajectories. As a result, there is tendency for using circular trajectory as seismic input to show conservative result of elasto-plastic seismic response analysis. 